\title{
Elevated plasma levels of the appetite-stimulator ACBP/DBI in fasting and obese subjects
}

\author{
Sijing Li ${ }^{1-3, \#}$, Adrien Joseph ${ }^{1-3, \#}$, Isabelle Martins ${ }^{1,2, *}$ and Guido Kroemer ${ }^{1,2,4-6, *}$ \\ ${ }^{1}$ Centre de Recherche des Cordeliers, Equipe labellisée par la Ligue contre le cancer, Inserm U1138, Université de Paris, Sorbonne \\ Université, Paris, France. \\ 2 Metabolomics and Cell Biology Platforms, Institut Gustave Roussy, Villejuif, France. \\ ${ }^{3}$ Faculté de Médecine, Université de Paris Saclay, Kremlin Bicêtre, France. \\ ${ }^{4}$ Pôle de Biologie, Hôpital Européen Georges Pompidou, AP-HP, Paris, France. \\ ${ }^{5}$ Suzhou Institute for Systems Medicine, Chinese Academy of Medical Sciences, Suzhou, China. \\ ${ }^{6}$ Karolinska Institute, Department of Women's and Children's Health, Karolinska University Hospital, Stockholm, Sweden. \\ \# SL and AJ equally contributed to this paper. \\ * Corresponding Authors: \\ Guido Kroemer, Equipe 11 labellisée par la Ligue contre le Cancer, Université de Paris, Sorbonne Université, INSERM U1138, Centre \\ de Recherche des Cordeliers, 75006 Paris, France; Phone: +33 14427 76 67; Fax: +33 1442776 74; E-mail: kroemer@orange.fr \\ Isabelle Martins, Equipe 11 labellisée par la Ligue contre le Cancer, Université de Paris, Sorbonne Université, INSERM U1138, Centre \\ de Recherche des Cordeliers, 75006 Paris, France; Phone: +33 1442776 62; Fax: +33 1442776 74; \\ E-mail: isabelle.martins@inserm.fr
}

\begin{abstract}
Eukaryotic cells release the phylogenetically ancient protein acyl coenzyme $A$ binding protein (ACBP, which in humans is encoded by the gene DBI, diazepam binding inhibitor) upon nutrient deprivation. Accordingly, mice that are starved for one to two days and humans that undergo voluntary fasting for one to three weeks manifest an increase in the plasma concentration of ACBP/DBI. Paradoxically, ACBP/DBI levels also increase in obese mice and humans. Since $A C B P / D B I$ stimulates appetite, this latter finding may explain why obesity constitutes a self-perpetuating state. Here, we present a theoretical framework to embed these findings in the mechanisms of weight control, as well as a bioinformatics analysis showing that, irrespective of the human cell or tissue type, one single isoform of ACBP/DBI (ACBP1) is preponderant ( $90 \%$ of all DBI transcripts, with the sole exception of the testis, where it is $\sim 70 \%)$. Based on our knowledge, we conclude that ACBP1 is subjected to a biphasic transcriptional and post-transcriptional regulation, explaining why obesity and fasting both are associated with increased circulating ACBP1 protein levels.
\end{abstract}

doi: $10.15698 /$ cst2021.07.252

Received originally: 14.05.2021;

in revised form: 11.06.2021

Accepted 14.06.2021.

Published 28.06.2021.

Keywords: metabolism, obesity, diazepam binding protein, appetite, starvation, autophagy.
Abbreviations:
ACBP - acyl coenzyme A binding protein,
$D B I$ - diazepam binding inhibitor, GABAAR- - -aminobutyric acid $A$ receptor.

\section{INTRODUCTION}

Acyl coenzyme A binding protein (ACBP), which in humans is encoded by the gene $D B I$ (diazepam binding inhibitor), is a phylogenetically ancient protein that is ubiquitously expressed by all nucleated human cell types [1-3]. Reflecting its double name, $A C B P / D B I$ has two distinct functions, namely as an intracellular contributor to fatty acid metabolism and as an extracellular mediator that binds to the $\gamma$-aminobutyric acid A receptor (GABAAR), competing for benzodiazepine binding (which explains the name $D B I$ ) and acting as an inverse agonist [4-6]. Recently, ACBP/DBI has been suggested to have a major obesogenic effect, based on the observation that intraperitoneal injection of recombinant $A C B P / D B I$ protein into mice stimulates food intake and lipo-anabolic reactions, while, conversely, neutralization of $A C B P / D B I$ by intraperitoneal injection of suitable antibodies reduces appetite and stimulates a lipo-catabolic metabolism, thereby preventing high-fat diet-induced obesity $[7,8]$.

Based on the likely pathophysiological relevance of $A C B P / D B I$ in appetite control [9], we investigated which isoforms of the protein are expressed in human tissues. Moreover, we screened transcription databases and reviewed the literature to understand why two apparently antinomic states, fasting and obesity can both result in an elevation of circulating ACBP/DBI protein levels. 


\section{ACBP/DBI ISOFORMS IN THE HUMAN TRANSCRIPTOME} According to the Uniprot website (https://www.uniprot.org/), ACBP/DBI may give rise to six different ACBP isoforms (numbered as ACBP1 to ACBP6) that have been detected by mRNA sequencing, as well as two additional isoforms (ACBP7 and ACBP8) that are predicted by computation based on the Uniprot dataset (https://www.uniprot.org/; Table 1). We subsequently identified the corresponding transcripts, whenever possible, as well as transcripts of the ACBP/DBI gene that, according to theoretical predictions, are unlikely to code for peptides/proteins. Of note, for the ACBP2 isoform, several distinct transcripts (which only differ in non-coding regions) have been identified by deep sequencing. We then interrogated the GTExPortal (https://www.gtexportal.org/home/) to define the relative abundance of each transcript in distinct human tissues. The transcript encoding the ACBP1 isoform was uniformly expressed at high levels (with the sole exception of whole blood cells), in accord with the observation that the ACBP protein (detected by immunohistochemistry) is present in all human tissues [9]. In all tissues, ACBP2 is the secondmost expressed isoform. Of note, in testis ACBP2 is encoded by a different transcript (ENST00000492375.1) than in all other organs (where transcript ENST000003111521.8 prevails). Moreover, testis is the sole organ that expresses significant levels of ACBP3. All other ACBP isoforms (ACBP4, ACBP5, ACBP6) were scarcely expressed (Fig. 1). The difference in the abundance of different ACBP isoforms becomes particularly clear when the expression level of all isoforms is set to $100 \%$. ACBP1 clearly represents the dominant $A C B P / D B I$ isoform (with values close to or higher than 90\%) with the sole exception of testis in which ACBP1 represents only $71 \%$ (Fig. 2). This may reflect the fact that the testicular transcriptome/proteome is unique due to expression of genes that are repressed in adult tissues, but transactivated in germline cells $[10,11]$. In conclusion, ACBP1 is the quantitatively most important $A C B P / D B I$ isoform expressed in human tissues.

\section{INCREASED ACBP/DBI PLASMA LEVELS UPON FASTING}

The ACBP/DBI orthologue from unicellular fungi (such as Cryptococcus neoformans, Pichia pastoris and Saccharomyces cerevisiae), filamentous fungi (such as Aspergillus oryzae) and facultatively multicellular slime molds (Dictyostelium discoideum) was found to be released upon nutrient depletion in an autophagy-dependent fashion [12-16]. Later, it was shown that mouse astrocytes release $A C B P / D B I$ in a way that requires the autophagy machinery to be effective [17]. A similar autophagy-dependent release mechanism for ACBP/DBI was documented for primary human or mouse cells, including circulating leukocytes and hepatocytes cultured under nutrient-free conditions, knowing that nutrient deprivation is one of the most important physiological stimuli of autophagy [7]. Indeed, this starvation-dependent release of ACBP/DBI concerns a preexisting pool of the protein and is not coupled to an increased transcription of the $A C B P / D B I$ gene [7]. In mice, starvation for 24 or 48 hours (which causes, respectively, 10 or $20 \%$ weight loss, along with the induction of autophagy) caused a reduction in the abundance of intracellular $A C B P / D B I$ in various organs (heart, kidney, liver, muscle) and a surge in ACBP/DBI plasma levels. This redistribution of $A C B P / D B I$ was inhibited in Atg $4 b$ knockout mice (which exhibit a partial autophagy defect) or by administration of two pharmacological inhibitors of autophagy, dimethyl $\alpha$-ketoglutarate and leupeptin [7]. In contrast, the levels of mRNA coding for ACBP/DBI tended to decrease upon starvation in the liver and white adipose tissue from mice [7]. These results suggest that the starvation-induced redistribution of pre-synthesized $A C B P / D B I$ protein depends on autophagy. Although ACBP/DBI is known to be secreted through an unconventional secretory pathway [7], the precise route for its autophagy-dependent release remains to be determined. In humans, voluntary fasting over one to three weeks leads to an increase in plasma ACBP/DBI concentrations [21], while dietary weight loss or weight loss induced by bariatric surgery was coupled to a decrease in ACBPDBI mRNA levels in periumbilical fat [7]. In sum, enhanced translocation of $A C B P / D B I$ protein from the intracellular to the extracellular space, rather than exacerbated $\mathrm{ACBP} / \mathrm{DB}$ I biosynthesis, explains the fasting-related augmentation of circulating $A C P B / D B I$ protein.

\section{INCREASED ACBP/DBI TRANSCRIPTION IN OBESITY}

Mice that become obese due to a high-fat diet or due to overconsumption of normal chow (due to the leptin deficiency found in animals with the $O b / O b$ genotype) express high levels of $A C B P / D B I$ mRNA in their livers and white adipose tissue [18]. Similarly, obese insulin-resistant Zucker rats exhibit abnormally high $\mathrm{ACBP} / \mathrm{DBI}$ levels in their skeleton muscles [19]. Weight gain in mice correlated with enhanced circulating ACBP/DBI concentrations. Since obesity is coupled to an inhibition of autophagy [20-22], it appears improbable that this effect may be explained by an enhanced autophagy-dependent release of ACBP/DBI protein from the intracellular space. Rather, an autophagyindependent release mechanism must account for this observation. Of note, in obese humans, an increase in plasma ACBP/DBI levels was observed as well. Thus, in four distinct independent cohorts, $\mathrm{ACBP} / \mathrm{DBI}$ concentrations significantly correlated with body mass index (BMI), contrasting with reduced circulating $A C B P / D B I$ levels in patients with anorexia nervosa [7, 23-25]. Moreover, circulating leukocytes from obese individuals contain more ACBP/DBI mRNA than white blood cells from lean subjects [26], and long-term dietary interventions reduced ACBP/DBI mRNA in subcutaneous fat from obese female patients (600 kcal/d for ten weeks) [27], as well as in visceral fat from non-diabetic men or women with overweight or obesity (800-1000 kcal/d for eight weeks) [28]. A similar reduction in abdominal fat ACBP/DBI mRNA was correlated with weight loss in a randomized dietary trial involving a twelve-week-long caloric restriction [29]. 
TABEL 1. Transcripts of the DBI gene and isoforms of the DBI protein.

\begin{tabular}{|c|c|c|c|c|c|c|c|c|}
\hline Isoform & Name & Transcript ID & bp & Translation ID & CCDS & UniProt & Exon & Amino acid sequences \\
\hline \multirow{6}{*}{ 1(ACBP-1a) } & \multirow{6}{*}{ DBI-202 } & \multirow{6}{*}{ ENST00000355857.8 } & \multirow{6}{*}{564} & \multirow{6}{*}{ ENSP00000348116.3 } & \multirow{6}{*}{ CCDS42740 } & \multirow{6}{*}{ P07108-1 } & $1-1-=$ & \multirow{6}{*}{$\begin{array}{l}\text { MSQAEFEKAAEEVRHLKTKPSDEEMLFIYGHYKQATVGDIN- } \\
\text { TERPGMLDFTGKAKWDAWNELKGTSKEDAMKAYINKVEELKKKYGI } \\
\text { (87 aa) }\end{array}$} \\
\hline & & & & & & & $\begin{array}{l}\text { ENSE00003772551/ENSE00003674746 } \\
\text { ENSE00003592668/ENSE00002317965 }\end{array}$ & \\
\hline & & & & & & & 1 (119366977-119367060_84bp) & \\
\hline & & & & & & & 2 (119368188-119368305_118bp) & \\
\hline & & & & & & & 3 (119370740-119370802_63bp) & \\
\hline & & & & & & & 4 (119372245-119372543_299bp) & \\
\hline \multirow{7}{*}{2 (ACBP-1b) } & \multirow{7}{*}{ DBI-201 } & \multirow{7}{*}{ ENST00000311521.8 } & \multirow{7}{*}{714} & \multirow{7}{*}{ ENSP00000311117.4 } & \multirow{7}{*}{ CCDS2126 } & \multirow{7}{*}{ P07108-2 } & $1-1-1-0$ & \multirow{7}{*}{$\begin{array}{l}\text { MWGDLWLLPPASANPGTGTEAEFEKAAEEVRHLKTKPSDEEMLFI- } \\
\text { YGHYKATVGDINTERPGMLAFTGKAKW- } \\
\text { DAWNELKGTSKEDAMKAYINKVEELKKKYGI (104 aa) }\end{array}$} \\
\hline & & & & & & & $\begin{array}{l}\text { ENSE00001425667/ENSE00001140850 } \\
\text { ENSE00003674746/ENSE00003592668 } \\
\text { ENSE00001202561 }\end{array}$ & \\
\hline & & & & & & & 1 (119367070-119367214_145bp) & \\
\hline & & & & & & & 2 (119367559-119367644_86bp) & \\
\hline & & & & & & & 3 (119368188-119368305_118bp) & \\
\hline & & & & & & & $4(119370740-119370802-63 \mathrm{bp})$ & \\
\hline & & & & & & & 5 (119372245-119372546_302bp) & \\
\hline \multirow{7}{*}{2 (ACBP-1b) } & \multirow{7}{*}{ DBI-204 } & \multirow{7}{*}{ ENST00000409094.5 } & \multirow{7}{*}{576} & \multirow{7}{*}{ ENSP00000386486.1 } & \multirow{7}{*}{ CCDS2126 } & \multirow{7}{*}{ P07108-2 } & $1-1-1-$ & \multirow{7}{*}{$\begin{array}{l}\text { MWGDLWLLPPASANPGTGTEAEFEKAAEEVRHLKTKPSDEEMLFI- } \\
\text { YGHYKQATVGDINTERPGMLDFTGKAKW- } \\
\text { DAWNELKGTSKEDAMKAYINKVEELKKKYGI (104 aa) }\end{array}$} \\
\hline & & & & & & & $\begin{array}{l}\text { ENSE00001582563/ENSE00001140850 } \\
\text { ENSE00003674746/ENSE00003592668 } \\
\text { ENSE00001585219 }\end{array}$ & \\
\hline & & & & & & & 1 (119366989-119367060_72bp) & \\
\hline & & & & & & & 2 (119367559-119367644_86bp) & \\
\hline & & & & & & & 3 (119368188-119368305_118bp) & \\
\hline & & & & & & & 4 (119370740-119370802_63bp) & \\
\hline & & & & & & & $5\left(119372245-119372481 \_237 \mathrm{bp}\right)$ & \\
\hline \multirow{7}{*}{2 (ACBP-1b) } & \multirow{7}{*}{ DBI-209 } & \multirow{7}{*}{ ENST00000535757.5 } & \multirow{7}{*}{740} & & & & $-1-1-1-0$ & \\
\hline & & & & & & & $\begin{array}{l}\text { ENSE00002250725/ENSE00001140850 } \\
\text { ENSE00003674746/ENSE00003592668 } \\
\text { ENSE00001931282 }\end{array}$ & MWGDLWLLPPASANPGTGTEAEFEKAAEEVRHLKTKPSDEEMLFI- \\
\hline & & & & ENSP00000439012.1 & CCDS2126 & P07108-2 & 1 (119366924-119367090_167bp) & YGHYKQATVGDINTERPGMLDFTGKAKW- \\
\hline & & & & & & & 2 (119367559-119367644_86bp) & DAWNELKGTSKEDAMKAYINKVEELKKKYGI (104 aa) \\
\hline & & & & & & & 3 (119368188-119368305_118bp) & \\
\hline & & & & & & & 4 (119370740-119370802_63bp) & \\
\hline & & & & & & & 5 (119372245-119372550_306bp) & \\
\hline & & & & & & & -1- - & MPAFAEFEKAAEEVRHLKTKPSDEEMLFIYGHYKQATVGDIN- \\
\hline & & & & & & & $\begin{array}{l}\text { ENSE00001514188/ENSE00003674746 } \\
\text { ENSE00003592668/ENSE00001852476 }\end{array}$ & (88 aа) \\
\hline $3(\mathrm{ACBP}-\mathrm{IC})$ & DBI-203 & ENSI00000393103.2 & 599 & ENSPO000003/6815.2 & CCDS42/41 & P0/108-3 & 1 (119367677-119367931_255bp) & \\
\hline & & & & & & & 2 (119368188-119368305_118bp) & \\
\hline & & & & & & & 3 (119370740-119370802_63bp) & \\
\hline & & & & & & & 4 (119372245-119372407_163bp) & \\
\hline
\end{tabular}


TABEL 1 (continued). Transcripts of the DBI gene and isoforms of the DBI protein.

\begin{tabular}{|c|c|c|c|c|c|c|c|c|}
\hline Isoform & Name & Transcript ID & bp & Translation ID & CCDS & UniProt & Exon & Amino acid sequences \\
\hline \multirow{8}{*}{$\begin{array}{l}4 \text { (ACBP-1a1- } \\
\text { g) }\end{array}$} & \multirow{8}{*}{ DBI-211 } & \multirow{8}{*}{ ENST00000627093.2 } & \multirow{8}{*}{554} & \multirow{8}{*}{ ENSP00000486281.1 } & \multirow{8}{*}{ CCDS54390 } & \multirow{8}{*}{ P07108-4 } & $1-1-1-$ & \multirow{8}{*}{$\begin{array}{l}\text { MSQHRAGRRGGVGKRGVRGRELGGQGKYGAGCSECGTRRI- } \\
\text { AARGEAEFEKAAEEVRHLKTKPSDEEMLFIYGHYKQATVGDIN- } \\
\text { TERPGMLDFTGKAKWDAWNELKGTSKEDAMKAYINKVEELKKKYGI } \\
\text { (129 aa) }\end{array}$} \\
\hline & & & & & & & ENSE00003772551/ENSE00003773620 & \\
\hline & & & & & & & ENSE00003674746/ENSE00003592668 & \\
\hline & & & & & & & ENSE00001852476 & \\
\hline & & & & & & & 1 (119366977-119367060_84bp) & \\
\hline & & & & & & & 2 (119367403-119367528_126bp) & \\
\hline & & & & & & & 4 (119370740-119370802_63bp) & \\
\hline & & & & & & & 5 (119372245-119372407_163bp) & \\
\hline \multirow{5}{*}{5 (ACBP-1g) } & \multirow{5}{*}{ DBI-212 } & \multirow{5}{*}{ ENST00000627305.2 } & \multirow{5}{*}{620} & \multirow{5}{*}{ ENSP00000486361.1 } & \multirow{5}{*}{ CCDS54391 } & \multirow{5}{*}{ P07108-5 } & $-1-1$ & \multirow{5}{*}{$\begin{array}{l}\text { MERWGKGLHGLEERGDSVPIP- } \\
\text { KHRAGRRGGVGKRGVRGRELGGQGKYGAGCSECGTRRIAARGE- } \\
\text { AEFEKAAEEVRHLKTKPSDEEMLFIYGHYKQATVGDINTERPGMLD- } \\
\text { FTGKAKWDAWNELKGTSKEDAMKAYINKVEELKKKYGI (148 aa) }\end{array}$} \\
\hline & & & & & & & $\begin{array}{l}\text { ENSE000003768948/ENSE00003674746 } \\
\text { ENSE00003592668/ENSE00001852476 }\end{array}$ & \\
\hline & & & & & & & 1 (119367253-119367528_276bp) & \\
\hline & & & & & & & 2 (119368188-119368305_118bp) & \\
\hline & & & & & & & 4 (119372245-119372407_163bp) & \\
\hline 6 (ACBP-1e) & - & - & - & - & - & P07108-6 & - & $\begin{array}{l}\text { MSQAEFEKAAEEVRHLKTKPSDEEMLFIYGHYKQATVG- } \\
\text { DINTGMQSGGWKGICSSKQAQQLRLEVPGNFTLKLPEALL- } \\
\text { FRWGMVMVPEVEKTMFRILSVSSSNRIQILVLEGLYWPSPAATLY } \\
\text { (123 aа) }\end{array}$ \\
\hline \multirow{8}{*}{7} & \multirow{8}{*}{ DBI-210 } & \multirow{8}{*}{ ENST00000542275.5 } & \multirow{8}{*}{757} & \multirow{8}{*}{ ENSP00000440698.2 } & \multirow{8}{*}{-} & \multirow{8}{*}{ AOAOAOMTI5 } & - - - - & \multirow{8}{*}{$\begin{array}{l}\text { MGWTSLCSGRGVGVEGAWRDGGRGCTDWRSEETQSPSRST- } \\
\text { GQDVAAEWGSEESVAESLEAEFEKAAEEVRHLKTKPSDEEMLFI- } \\
\text { YGHYKQATVGDINTERPGMLDFTGKAKW- } \\
\text { DAWNELKGTSKEDAMKAYINKVEELKKKYGI (143 aа) }\end{array}$} \\
\hline & & & & & & & ENSE00003720718/ENSE00002257304 & \\
\hline & & & & & & & $\begin{array}{l}\text { ENSE000003674746/ENSE00003592668 } \\
\text { ENSE00001852476 }\end{array}$ & \\
\hline & & & & & & & 1 (119367048-119367334_287bp) & \\
\hline & & & & & & & 2 (119367338-119367463_126bp) & \\
\hline & & & & & & & 3 (119368188-119368305_118bp) & \\
\hline & & & & & & & 4 (119370740-119370802_63bp) & \\
\hline & & & & & & & 5 (119372245-119372407_163bp) & \\
\hline \multirow{6}{*}{8} & \multirow{6}{*}{ DBI-208 } & \multirow{6}{*}{ ENST00000535617.5 } & \multirow{6}{*}{654} & \multirow{6}{*}{ ENSP00000442917.2 } & \multirow{6}{*}{ CCDS74568 } & & $-1-1-0$ & \\
\hline & & & & & & & $\begin{array}{l}\text { ENSE00002282645/ENSE00003674746 } \\
\text { ENSE00003592668/ENSE00001931282 }\end{array}$ & MSQVQRVHSQAAKAEFEKAAEEVRHLKTKPSDEEMLFIYGHYK- \\
\hline & & & & & & B8ZWD1 & 1 (119366924-119367090_167bp) & QATVGDINTERPGMLDFTGKAKWDAWNELKGTSKEDAMKAYIN- \\
\hline & & & & & & & 2 (119368188-119368305_118bp) & KVEELKKKYGI (97 aa) \\
\hline & & & & & & & 3 (119370740-119370802_63bp) & \\
\hline & & & & & & & 4 (119372245-119372550_306bp) & \\
\hline
\end{tabular}


TABEL 1 (continued). Transcripts of the DBI gene and isoforms of the DBI protein.

\begin{tabular}{|c|c|c|c|c|c|c|c|c|}
\hline Isoform & Name & Transcript ID & bp & Translation ID & CCDS & UniProt & Exon & Amino acid sequences \\
\hline \multirow{6}{*}{-} & \multirow{6}{*}{ DBI-205 } & \multirow{6}{*}{ ENST00000460901.1 } & \multirow{6}{*}{774} & \multirow{6}{*}{-} & \multirow{6}{*}{-} & \multirow{6}{*}{ - } & - - - - & \multirow{6}{*}{ No protein } \\
\hline & & & & & & & $\begin{array}{l}\text { ENSE00001937885/ENSE00003658460 } \\
\text { ENSE00003634772/ENSE00001843688 }\end{array}$ & \\
\hline & & & & & & & 1 (119367081-119367463_383bp) & \\
\hline & & & & & & & 2 (119368188-119368305_118bp) & \\
\hline & & & & & & & 3 (119370740-119370802_63bp) & \\
\hline & & & & & & & $4\left(119372245-119372454 \_210 \mathrm{bp}\right)$ & \\
\hline \multirow{4}{*}{-} & \multirow{4}{*}{ DBI-206 } & \multirow{4}{*}{ ENST00000475783.1 } & \multirow{4}{*}{842} & \multirow{4}{*}{ - } & \multirow{4}{*}{-} & \multirow{4}{*}{ - } & - & \multirow{4}{*}{ No protein } \\
\hline & & & & & & & ENSE00001895774/ENSE00001891815 & \\
\hline & & & & & & & 1 (119370217-119370802_586bp) & \\
\hline & & & & & & & 2 (119372245-119372500_256bp) & \\
\hline \multirow{4}{*}{-} & \multirow{4}{*}{ DBI-207 } & \multirow{4}{*}{ ENST00000492375.1 } & \multirow{4}{*}{784} & \multirow{4}{*}{ - } & \multirow{4}{*}{-} & \multirow{4}{*}{ - } & -2 & \multirow{4}{*}{ No protein } \\
\hline & & & & & & & ENSE00001814896/ENSE00001958680 & \\
\hline & & & & & & & 1 (119366935-119367060_126bp) & \\
\hline & & & & & & & 2 (119368188-119368845_658bp) & \\
\hline
\end{tabular}

Note: Isoforms 1-6: 6 described isoforms; Isoforms 7-8: 2 potential isoforms that are computationally mapped. The information are obtained from Uniprot dataset (https://www.uniprot.org/) and e!Ensembl

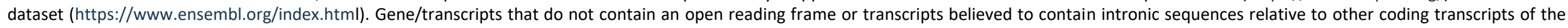
same gene were considered unlikely to code for ACBP isoforms.

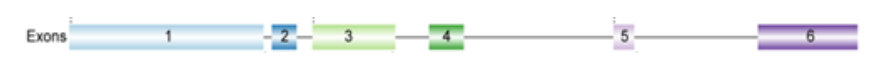




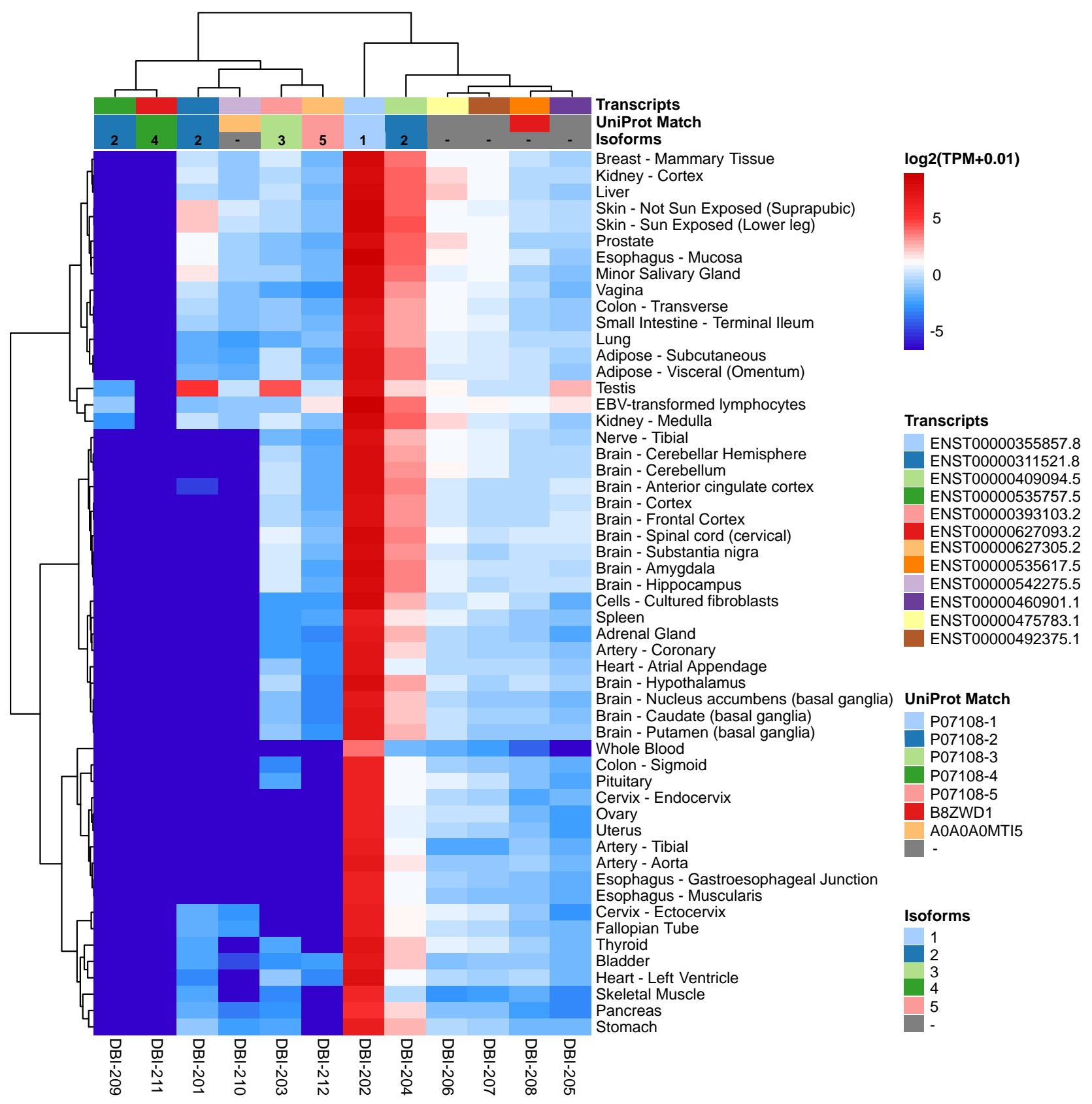

FIGURE 1: The expression of DBI isoforms in human tissues. The data were obtained from GTExPortal database (https://www.gtexportal.org/home/) on April, 7th 2021. Expression values are shown in TPM (Transcripts per million, binary logarithmic scale).

In sum, the available evidence suggests that obesity is linked to enhanced transcription of the ACBP/DBI gene, resulting in elevated ACBP/DBI levels.

\section{ACBP/DBI IN THE PATHOGENESIS OF OBESITY}

Starved mice usually exhibit a hyperphagic response when they are allowed to access food pellets. This hyperphagic response can be blocked by injecting a neutralizing antibody against ACBP/DBI into the peritoneal cavity. In contrast, intravenous or intraperitoneal administration of recombinant $A C B P / D B I$ protein (isoform 1) to fed mice inhib- its autophagy and was sufficient to induce a rapid hyperphagic response $[7,30]$. This latter effect involves GABA receptors of the $A$ type (GABAAR) because mice bearing a point mutation (F77I) in the GABAAR 2 subunit that reduces $A C B P / D B I$ binding [31] fail to increase food intake after $A C B P / D B I$ injection [24]. Thus, the starvation-induced surge in plasma ACBP/DBI may be part of a "hunger reflex" assuring the maintenance of energy and body mass homeostasis $[32,33]$. As true for most if not all homeostatic circuitries, this "hunger reflex" would involve a negative feedback loop in which extracellular ACBP/DBI acting on GABAAR 


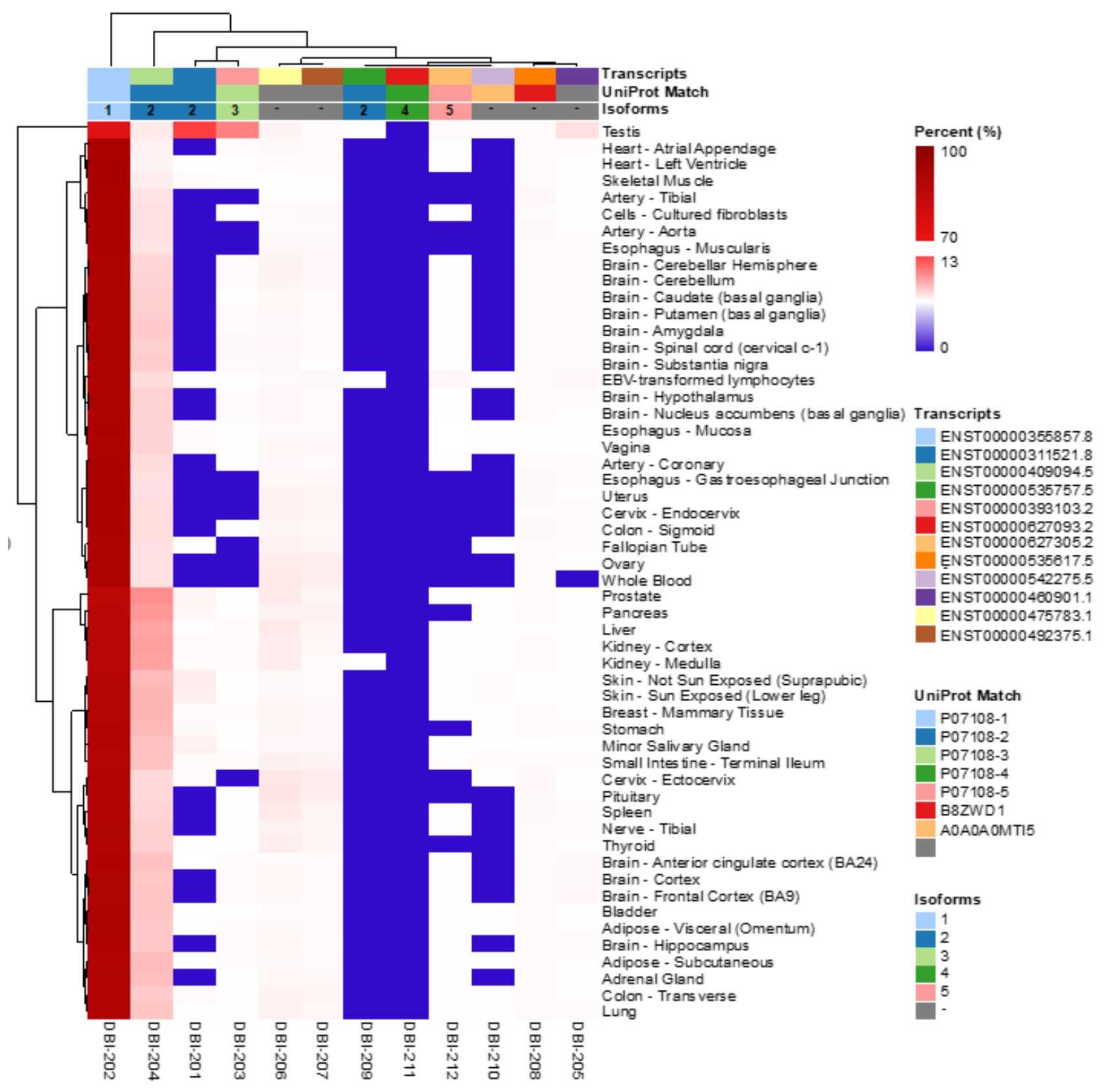

FIGURE 2: The proportion of DBI isoforms in human tissues. The data were obtained from GTExPortal database (https://www.gtexportal.org/home/) on April, 7th 2021. Expression values are shown in percentages of the different isoforms in the corresponding tissue.

would be embedded (Fig. 3). In this scenario, starvationinduced autophagy would lead to a surge in extracellular ACBP/DBI, which then acts on GABAAR to stimulate food intake. Once energy and body mass homeostasis are ensured, cessation of autophagy and degradation of circulating $A C B P / D B I$ would cause $A C B P / D B I$ concentrations to return to the basal level, hence closing the homeostatic circuitry.

Contrasting with physiological regulation based on feedback loops, pathologies are often characterized by self-amplifying ("vicious") feedforward circuitries [34]. As discussed above, obesity is associated with enhanced $A C B P / D B I$ mRNA expression in various organs (e.g. subcutaneous and visceral fat, peripheral blood), as well as with increased levels of circulating ACBP/DBI protein. Thus, the scenario emerges that, in obesity, ACBP/DBI plasma concentrations are constitutively elevated, maintaining a high level of caloric intake, hence perpetuating ACBP upregulation (Fig 3). It is tempting to speculate that this pathogenic feedforward circuitry is activated on a different, chronic time scale (which involves transcriptional mechanisms), differing from the physiological feedback regulation, which 


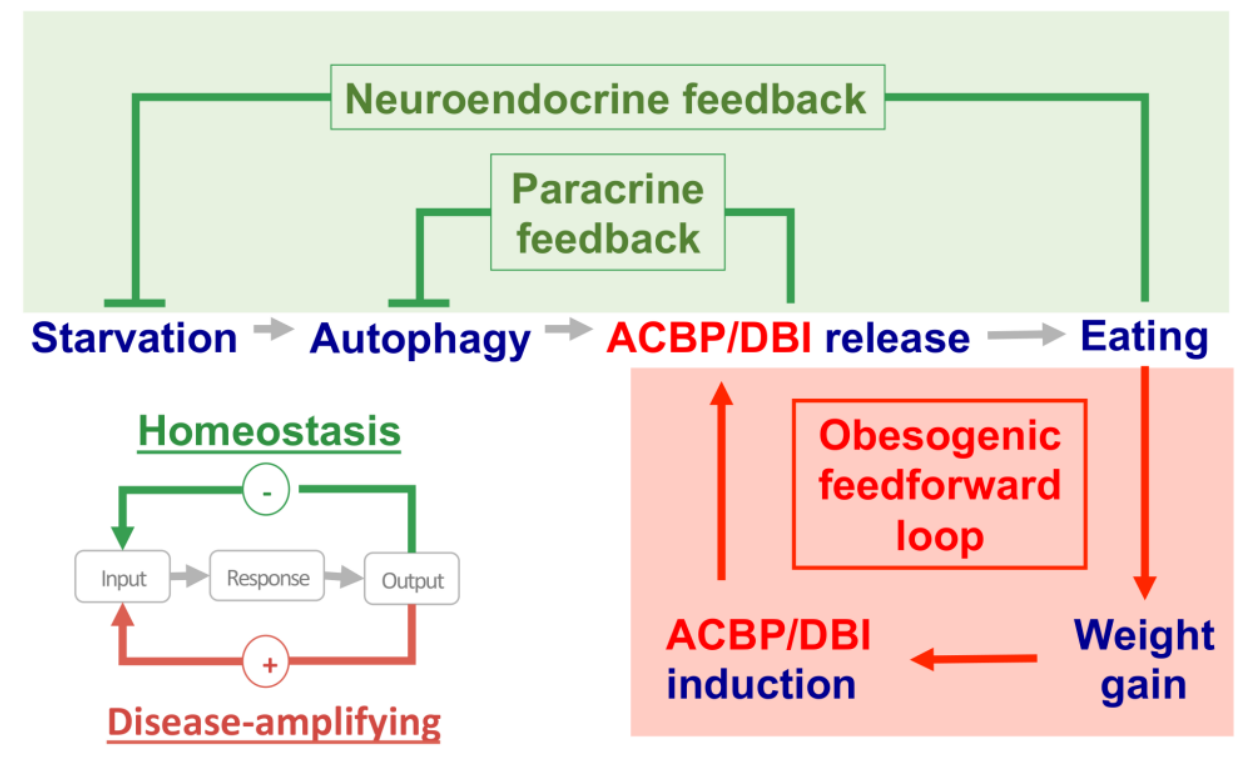

FIGURE 3: Hypothetical involvement of the appetite-stimulatory effects of ACBP/DBI-in two distinct circuitries: (i) an acute neuroendocrine feedback loop that is activated by starvation or fasting and involves the release of pre-formed ACBP/DBI protein from the intracellular to the extracellular space by a mechanism that involves autophagy and (ii) a chronic feedforward loop in which obesity-associate weight gain causes an increase in ACBP/DBI protein levels, likely through transcriptional activation of the $A C B P / D B /$ gene. While the feedback loop would reflect homeostatic regulation for the maintenance of energy balance, the feedforward loop would participate in the pathogenesis of obesity. occurs in an acute, reflex-like fashion (mostly via nontranscriptional mechanisms, such as an autophagyassociated cellular release mechanism). Obesity-induced activation of PPARy could play a role in the upregulation of $A C B P / D B I$, as members of the PPAR and SREBP families have been shown to enhance transcription of the $A C B P / D B I$ gene above baseline levels [35]. Nonetheless, the exact mechanisms accounting for the pathogenic upregulation of $A C B P / D B I$ in obesity remain enigmatic. In particular, the transcription factor(s) activating the $A C B P / D B$ I gene, as well as a possible epigenetic regulation, remain to be identified. Moreover, the mechanisms accounting for the passive leakage or active secretion of ACBP/DBI from adipocytes and other cell types are elusive. We anticipate that the elucidation of these pending questions will yield important insights into the pathogenesis of eating and weight disorders.

\section{ACKNOWLEDGMENTS}

GK is supported by the Ligue contre le Cancer (équipe labellisée); Agence National de la Recherche (ANR) - Projets blancs; AMMICa US23/CNRS UMS3655; Association pour la recherche sur le cancer (ARC); Association "Ruban Rose"; Cancéropôle lle-de-France; Fondation pour la Recherche Médicale (FRM); a donation by Elior; Equipex Onco-Pheno-Screen; European Joint Programme on Rare Diseases (EJPRD); Gustave Roussy Odyssea, the European Union Horizon 2020 Projects Oncobiome and Crimson; Fondation Carrefour; High-end Foreign Expert Program in China (GDW20171100085), Institut National du Cancer (INCa); Inserm (HTE); Institut Universitaire de

\section{REFERENCES}

1. Qiu S, and Zeng B (2020). Advances in Understanding the Acyl-CoABinding Protein in Plants, Mammals, Yeast, and Filamentous Fungi. J Fungi Basel Switz 6(1): 34. doi: 10.3390/jof6010034

2. Thomas AM, Asnicar F, Kroemer G, and Segata N (2021). Microbial $\mathrm{ACBP} / \mathrm{DBI}$-like genes are rare in the human gut microbiome and show
France; LabEx Immuno-Oncology (ANR-18-IDEX-0001); the Leducq Foundation; the RHU Torino Lumière; Seerave Foundation; SIRIC Stratified Oncology Cell DNA Repair and Tumor Immune Elimination (SOCRATE); and SIRIC Cancer Research and Personalized Medicine (CARPEM). This study contributes to the IdEx Université de Paris ANR-18-IDEX-0001.

$A J$ is supported by a grant from "Fondation ARC pour la recherche sur le cancer".

\section{CONFLICT OF INTEREST}

G.K. has filed patent application dealing with targeting the $\mathrm{ACBP} / \mathrm{DBI}$ system in anorexia, obesity, and co-morbidities, as well as patent applications dealing with caloric restriction mimetics (autophagy inducers) for the treatment of aging, age-related diseases, cancer, obesity, and comorbidities. G.K. is a scientific co-founder of everImmune, Samsara Therapeutics and Therafast Bio.

\section{COPYRIGHT}

(C) $2021 \mathrm{Li}$ et al. This is an open-access article released under the terms of the Creative Commons Attribution (CC BY) license, which allows the unrestricted use, distribution, and reproduction in any medium, provided the original author and source are acknowledged.

Please cite this article as: Sijing Li, Adrien Joseph, Isabelle Martins and Guido Kroemer (2021). Elevated plasma levels of the appetite-stimulator ACBP/DBI in fasting and obese subjects. Cell Stress 5(7): 89-98. doi: 10.15698/cst2021.07.252

no links with obesity. Appl Environ Microbiol 87(12):e0047121. doi: 10.1128/AEM.00471-21

3. Charmpilas N, Ruckenstuhl C, Sica V, Büttner S, Habernig L, Dichtinger S, Madeo F, Tavernarakis N, Bravo-San Pedro JM, and Kroemer G (2020). Acyl-CoA-binding protein (ACBP): a phylogenetically conserved 
appetite stimulator. Cell Death Dis 11(1): 7. doi: 10.1038/s41419-0192205-x

4. Guidotti A, Toffano G, and Costa E (1978). An endogenous protein modulates the affinity of GABA and benzodiazepine receptors in rat brain. Nature 275(5680): 553-555. doi: 10.1038/275553a0

5. Guidotti A, Forchetti CM, Corda MG, Konkel D, Bennett CD, and Costa $E$ (1983). Isolation, characterization, and purification to homogeneity of an endogenous polypeptide with agonistic action on benzodiazepine receptors. Proc Natl Acad Sci U S A 80(11): 3531-3535. doi: 10.1073/pnas.80.11.3531

6. Ohkuma S, Katsura M, and Tsujimura A (2001). Alterations in cerebral diazepam binding inhibitor expression in drug dependence: a possible biochemical alteration common to drug dependence. Life Sci 68(11): 1215-1222. doi: 10.1016/s0024-3205(00)01031-6

7. Bravo-San Pedro JM et al. (2019). Acyl-CoA-Binding Protein Is a Lipogenic Factor that Triggers Food Intake and Obesity. Cell Metab 30(4): 754-767.e9. doi: 10.1016/j.cmet.2019.07.010

8. Bravo-San Pedro JM, Sica V, Martins I, Anagnostopoulos G, Maiuri C and Kroemer G (2019). Cell-autonomous, paracrine and neuroendocrine feedback regulation of autophagy by DBI/ACBP (diazepam binding inhibitor, acyl-CoA binding protein): the obesity factor. Autophagy 15(11): 2036-2038. doi: 10.1080/15548627.2019.1662585

9. Montégut L, Lopez-Otin C, Magnan C, and Kroemer G (2021). Old Paradoxes and New Opportunities for Appetite Control in Obesity. Trends Endocrinol Metab TEM 32(5): 264-294. doi: 10.1016/j.tem.2021.02.005

10. Sohni A, Tan K, Song H-W, Burow D, de Rooij DG, Laurent L, Hsieh T-C, Rabah R, Hammoud SS, Vicini E, and Wilkinson MF (2019). The Neonatal and Adult Human Testis Defined at the Single-Cell Level. Cell Rep 26(6): 1501-1517.e4. doi: 10.1016/j.celrep.2019.01.045

11. Jung M, Wells D, Rusch J, Ahmad S, Marchini J, Myers SR, and Conrad DF (2019). Unified single-cell analysis of testis gene regulation and pathology in five mouse strains. elife 8: e43966. doi: 10.7554/eLife. 43966

12. Kinseth MA, Anjard C, Fuller D, Guizzunti G, Loomis WF, and Malhotra $V$ (2007). The Golgi-associated protein GRASP is required for unconventional protein secretion during development. Cell 130(3): 524-534. doi: 10.1016/j.cell.2007.06.029

13. Manjithaya R, Anjard C, Loomis WF, and Subramani S (2010). Unconventional secretion of Pichia pastoris Acb1 is dependent on GRASP protein, peroxisomal functions, and autophagosome formation. J Cell Biol 188(4): 537-546. doi: 10.1083/jcb.200911149

14. Duran JM, Anjard C, Stefan C, Loomis WF, and Malhotra V (2010). Unconventional secretion of Acb1 is mediated by autophagosomes. J Cell Biol 188(4): 527-536. doi: 10.1083/jcb.200911154

15. Xu X, Zhao Y, Kirkman E, and Lin X (2016). Secreted Acb1 Contributes to the Yeast-to-Hypha Transition in Cryptococcus neoformans. Appl Environ Microbiol 82(4): 1069-1079. doi: 10.1128/AEM.0369115

16. Kwon HS, Kawaguchi K, Kikuma T, Takegawa K, Kitamoto K, and Higuchi $Y$ (2017). Analysis of an acyl-CoA binding protein in Aspergillus oryzae that undergoes unconventional secretion. Biochem Biophys Res Commun 493(1): 481-486. doi: 10.1016/j.bbrc.2017.08.166

17. Loomis WF, Behrens MM, Williams ME, and Anjard C (2010). Pregnenolone sulfate and cortisol induce secretion of acyl-CoA-binding protein and its conversion into endozepines from astrocytes. J Biol Chem 285(28): 21359-21365. doi: 10.1074/jbc.M110.105858

18. Waller-Evans $H$, Hue C, Fearnside J, Rothwell AR, Lockstone HE, Caldérari S, Wilder SP, Cazier J-B, Scott J, and Gauguier D (2013). Nutrigenomics of high fat diet induced obesity in mice suggests relation- ships between susceptibility to fatty liver disease and the proteasome. PloS One 8(12): e82825. doi: 10.1371/journal.pone.0082825

19. Franch J, Knudsen J, Ellis BA, Pedersen PK, Cooney GJ, and Jensen J (2002). Acyl-CoA binding protein expression is fiber type- specific and elevated in muscles from the obese insulin-resistant Zucker rat. Diabetes 51(2): 449-454. doi: 10.2337/diabetes.51.2.449

20. López-Otín C, Galluzzi L, Freije JMP, Madeo F, and Kroemer G (2016). Metabolic Control of Longevity. Cell 166(4): 802-821. doi: 10.1016/j.cell.2016.07.031

21. Hazari Y, Bravo-San Pedro JM, Hetz C, Galluzzi L, and Kroemer G (2020). Autophagy in hepatic adaptation to stress. J Hepatol 72(1): 183-196. doi: 10.1016/j.jhep.2019.08.026

22. Maiuolo J, Gliozzi M, Musolino V, Carresi C, Scarano F, Nucera S, Scicchitano M, Bosco F, Ruga S, Zito MC, Macri R, Bulotta R, Muscoli C and Mollace $V$ (2021). From Metabolic Syndrome to Neurological Diseases: Role of Autophagy. Front Cell Dev Biol 9: 651021. doi: 10.3389/fcell.2021.651021

23. Conti E, Tremolizzo L, Bomba M, Uccellini O, Rossi MS, Raggi ME, Neri F, Ferrarese C, and Nacinovich R (2013). Reduced fasting plasma levels of diazepam-binding inhibitor in adolescents with anorexia nervosa. Int J Eat Disord 46(6): 626-629. doi: 10.1002/eat.22129

24. Joseph A et al. (2020). Metabolic and psychiatric effects of acyl coenzyme $A$ binding protein (ACBP)/diazepam binding inhibitor (DBI). Cell Death Dis 11(7): 502. doi: 10.1038/s41419-020-2716-5

25. Joseph A, Chen $H$, Anagnostopoulos $G$, Montégut L, Lafarge $A$, Motiño O, Castedo M, Maiuri MC, Clément K, Terrisse S, Martin AL, Vaz-Luis I, Andre F, Grundler F, de Toledo FW, Madeo F, Zitvogel L, Goldwasser F, Blanchet B, Fumeron F, Roussel R, Martins I, Kroemer G (2021). Effects of acyl coenzyme $A$ binding protein (ACBP)/diazepam binding inhibitor (DBI) on body mass index. Cell Death Dis 12(6):599. doi: 10.1038/s41419-021-03864-9

26. Ghosh S, Dent R, Harper M-E, Gorman SA, Stuart JS, and McPherson $R$ (2010). Gene expression profiling in whole blood identifies distinct biological pathways associated with obesity. BMC Med Genomics 3: 56. doi: 10.1186/1755-8794-3-56

27. Dahlman I, Linder K, Arvidsson Nordström E, Andersson I, Lidén J, Verdich C, Sørensen TIA, and Arner P (2005). Changes in adipose tissue gene expression with energy-restricted diets in obese women. Am J Clin Nutr 81(6): 1275-1285. doi: 10.1093/ajcn/81.6.1275

28. Armenise C, Lefebvre G, Carayol J, Bonnel S, Bolton J, Di Cara A, Gheldof N, Descombes P, Langin D, Saris WH, Astrup A, Hager J, Viguerie $\mathrm{N}$, and Valsesia $A$ (2017). Transcriptome profiling from adipose tissue during a low-calorie diet reveals predictors of weight and glycemic outcomes in obese, nondiabetic subjects. Am J Clin Nutr 106(3): 736-746. doi: 10.3945/ajcn.117.156216

29. Schübel R, Sookthai D, Greimel J, Johnson TS, Grafetstätter ME, Kirsten R, Kratz M, Ulrich CM, Kaaks R, and Kühn T (2019). Key Genes of Lipid Metabolism and WNT-Signaling Are Downregulated in Subcutaneous Adipose Tissue with Moderate Weight Loss. Nutrients 11(3): 639. doi: 10.3390/nu11030639

30. Sica V, Martins I, Motiño O, Bravo-San Pedro JM, and Kroemer G (2020). Antibody-mediated neutralization of ACBP/DBI has anorexigenic and lipolytic effects. Adipocyte 9(1): 116-119. doi: 10.1080/21623945.2020.1736734

31. Wulff $P$, Goetz $T$, Leppä $E$, Linden A-M, Renzi $M$, Swinny JD, Vekovischeva OY, Sieghart W, Somogyi P, Korpi ER, Farrant M, and Wisden W (2007). From synapse to behavior: rapid modulation of defined neuronal types with engineered GABAA receptors. Nat Neurosci 10(7): 923-929. doi: 10.1038/nn1927 
32. Madeo F, Tavernarakis N, Pedro JMB-S, and Kroemer G (2020). ACBP is an appetite stimulator across phylogenetic barriers. Cell Stress 4(2): 27-29. doi: 10.15698/cst2020.02.211

33. Pedro JMB-S, Sica V, Madeo F, and Kroemer G (2019). Acyl-CoAbinding protein (ACBP): the elusive "hunger factor" linking autophagy to food intake. Cell Stress 3(10): 312-318. doi: 10.15698/cst2019.10.200
34. López-Otín C, and Kroemer G (2021). Hallmarks of Health. Cell 184(1): 33-63. doi: 10.1016/j.cell.2020.11.034

35. Neess D, Kiilerich P, Sandberg MB, Helledie T, Nielsen R, Mandrup $S$ (2006). ACBP - a PPAR and SREBP modulated housekeeping gene. Mol Cell Biochem 284(1):149-57. doi: 10.1007/s11010-005-9039-9 